\title{
TERRITÓRIOS PERANTE A GLOBALIZAÇÃO EM SANTA CATARINA: ENSAIO INSPIRADO NA IDEIA DE "SOCIOLOGIA DO LUGAR"
}

Hoyêdo Nunes Lins ${ }^{1}$

Resumo: O debate sobre a globalização registra o problema dos desafios enfrentados pelos territórios subnacionais. Diversos estudos constatam que a geografia dos efeitos é desigual, algumas áreas saindo-se melhor do que outras frente aos problemas (e oportunidades). A diferenciação justificaria análises nos termos do que se chamaria de "sociologia do lugar", atenta para atributos sociais, econômicos, culturais e institucionais. Este estudo foca tal assunto abordando três áreas de Santa Catarina: o Vale do Itajaí têxtil e do vestuário, o norte moveleiro e o oeste agroindustrial, cujos traços se constituíram nas respectivas histórias. Com base em pesquisa bibliográfica e documental, fala-se sobre as reações aos desafios, que variaram da reestruturação produtiva à persistência de condutas depois tornadas problemáticas.

Palavras-chave: Território. Globalização. Desenvolvimento. Santa Catarina

\section{TERRITORIES IN FACE OF GLOBALIZATION IN SANTA CATARINA: AN ESSAY INSPIRED BY THE IDEA OF "SOCIOLOGY OF PLACE"}

Abstract: The globalization debate attaches importance to the challenges faced by subnational territories. According to several studies, the effects are unevenly distributed: in some areas the results are better (or worse) than in others. The differentiation seems to justify approaches in terms of what one could call "sociology of place", paying attention to social, economic, cultural and institutional attributes. This study focuses on this subject by addressing three areas of Santa Catarina: the Vale do Itajaí, with textiles and clothing production, the North, with furniture activities, and the West, were agroindustry reigns, whose features were historically constituted. Based on bibliographic and documentary research, local reactions ranging from the restructuring to the persistence of behaviors that became problematic are looked upon.

Keywords: Territory. Globalization. Development. Santa Catarina

\section{LOS TERRITORIOS Y LA GLOBALIZACIÓN EN SANTA CATARINA: ENSAYO INSPIRADO EN LA IDEA DE "SOCIOLOGÍA DEL LUGAR"}

Resumen: El debate sobre la globalización registra los desafíos que enfrentan los territorios subnacionales. Varios estudios sugieren que la geografía de los efectos es desigual, porque algunas áreas obtienen mejores resultados que otras. La diferenciación justificaría análisis en términos de "sociología del lugar", prestando atención a los atributos sociales, económicos, culturales e institucionales. Este estudio explora este tema al abordar tres áreas de Santa Catarina: el valle de Itajaí (textiles y vestimenta), el norte (muebles) y el oeste (agroindústria), cuyas características se constituyeron en las historias respectivas. La base es uma

1 Universidade Federal de Santa Catarina, Programas de Pós-Graduação em Economia e em Relações Internacionais, Florianópolis, Brasil, hoyedo.lins@ufsc.br, https://orcid.org/0000-0001-7438- 
investigación bibliográfica y documental, y el análisis habla de las reacciones locais, que variaron desde la reestructuración productiva hasta la persistencia de comportamientos problemáticos.

Palabras clave: Territorio. Globalización. Desarrollo. Santa Catarina

\section{Introdução}

Foi crescente desde o segundo pós-guerra o interesse pela dimensão espacial do desenvolvimento. No debate sobre a globalização, essa atenção se aprofundou pelos incrustados desafios e ameaças às estruturas socioeconômicas, políticas e institucionais em várias escalas espaciais. Não surpreende que "territórios em face da globalização" tenha se tornado expressão incidente em várias agendas de pesquisa.

A correspondente literatura indica que os territórios não são afetados do mesmo modo pelos processos ligados à globalização. Mormente quanto à economia, alguns saem-se melhor do que outros perante as pressões, e isso outorga sentido a abordagens nos termos do que se pode chamar de "sociologia do lugar". O escopo de tais estudos abrange o modo como, devido aos existentes atributos e particularidades, distintos locais são atingidos e reagem.

Este artigo representa uma investida nessa direção. Três situações em Santa Catarina são observadas: as dos setores têxtil-vestuário no Vale do Itajaí, moveleiro ao norte e agroindustrial no oeste. Todos se destacam economicamente no estado, inclusive em exportações, apresentando estruturas que, de uma maneira ou de outra, foram afetadas pela globalização. Os reflexos, apontados aqui de forma exploratória, revelam algumas particularidades.

$\mathrm{Na}$ estrutura do artigo, sistematiza-se a seguir literatura sobre o papel dos atributos territoriais nas interações entre processos ocorrendo nos planos local e global. Depois desenvolvem-se os estudos sobre o Vale do Itajaí, o norte e o oeste catarinense, em partes próprias do texto. Breves comentários comparando e discutindo as três situações regionais precedem às considerações finais.

\section{Considerações de natureza conceitual}

De uso disseminado e controverso, o termo globalização evoca ao menos, na esfera econômica, o aprofundamento da feição internacional de processos envolvendo investimentos, produção e comércio (HARVEY, 1995). Representam-Ihe vetor básico as empresas multinacionais, cujas atividades afetam mais do que nunca 
a paisagem do capitalismo. A emergência e o destaque da questão relativa às cadeias globais de valor são sugestivos a respeito (OECD, 2013).

\section{Territórios perante a globalização}

O aumento das interdependências, inerente à globalização, sinaliza desafios e oportunidades em vários níveis e escalas (RODRIK, 1997). Os territórios enfrentam aumento da concorrência, e a mobilidade do capital - via instalações produtivas ou relações de subcontratação - tende a provocar ou nutrir declínios geradores de crises nas áreas de origem (JONES; KIERZKOWSKI, 2005). Literatura produzida já nos anos 1980, antes que se multiplicassem as referências à globalização, documentou e analisou situações desse tipo (CARNEY; HUDSON; LEWIS, 1980).

Nas áreas de destino dos fluxos, tende-se a lograr (maior) inserção nas relações globalizadas, não raramente acenando com revitalização econômica, por exemplo. Mas, fora do centro do capitalismo, costuma ser alto o interesse das grandes empresas em normas trabalhistas e ambientais frouxas e em salários baixos. A consequência é a frustração de objetivos como elevação da renda e, de uma maneira geral, promoção do desenvolvimento (SHEPHERD; STONE, 2013).

Literatura florescente desde os anos 1980 salienta aspectos que passaram a frequentar abordagens sobre as possibilidades dos territórios na globalização. Com inspiração, de algum modo, na análise de Marshall (1979) sobre aglomerações produtivas especializadas - envolvendo externalidades, divisão dos processos de fabricação entre unidades autônomas de trabalho e "atmosfera industrial" -, ganhou vulto uma perspectiva que realça o dinamismo interno dos territórios.

Por esse ângulo, os territórios são em geral considerados construções sociais históricas, com traços socioculturais, econômicos, institucionais e políticos (VANIER, 2009), a diversidade de situações e análises transparecendo em coletâneas como Benko e Lipietz (1992, 2000). Distritos industriais marshallianos, sistemas produtivos locais ou sistemas industriais localizados destacam-se nas discussões, realçando-se a especialização flexível nos processos produtivos. Note-se que os escritos não evitam a crítica ao que, pelo peso dos processos globais, alguns autores veem como ênfase excessiva no dinamismo interno (ou endógeno) de regiões ou locais.

Nesses ambientes, ações cooperativas e crivadas de sentido de reciprocidade, lado a lado com uma forte concorrência e estimuladas pelo suporte representado por tecidos institucionais "espessos" e ativos, impulsionariam a 
valorização das capacidades locais e repercutiriam em qualidade e competitividade. Parcerias e "contratualizações" duradouras, escoradas em confiança mútua e espírito comunitário, são aspectos sublinhados em maior ou menor grau nos estudos, conforme as circunstâncias e as experiências concretas.

\section{Por uma "sociologia do lugar"}

Cooperação, reciprocidade e parcerias geralmente implicam condutas, canalizadas por governança ou regulação no plano territorial (STORPER; HARRISON, 1991), que se expressam, por assim dizer, em condizente "sociologia do lugar". Evoca-se nas análises sobre tais realidades, de fato, um "[...] efeito societal local; uma especificidade [...] quanto à cultura do vínculo social' [...]." (LIPIETZ, 2001, p.8, nossa tradução). É sugestivo, a respeito, que Becattini (1992, p. 36) designe o distrito marshalliano como uma "entidade socioterritorial".

As atitudes nas interações com essa índole não são desinteressadas, embora comportamentos movidos por altruísmo não possam ser excluídos. Avultaria em tais realidades a percepção de que a ação coletiva, como o enfrentamento conjunto das adversidades, tende a produzir maiores benefícios individuais. Ajuda essa ideia 0 fato de que a difusão do conhecimento, a aprendizagem e a inovação, cruciais na concorrência, representam dinâmicas amplamente territoriais - pois são muito importantes os contatos face a face e as externalidades - e permeadas de vínculos cooperativos (LUNDVALL; BORRÁS, 1997).

A literatura assinala que os traços socioculturais dos ambientes influenciam os processos que nutrem condutas com esse espírito, impulsionando o enfrentamento dos problemas e, pelo aproveitamento das oportunidades surgidas, promovendo o desenvolvimento. Perpassa essa abordagem, de algum modo, a ideia de enraizamento (embeddedness), explorada por Granovetter (1985, p.487, nossa tradução) para postular que as ações intencionais dos atores estão sempre "[...] enraizadas em sistemas de relações sociais concretas e em curso." Quer dizer, a influência dos ambientes é incontornável: "Os atores não se comportam ou decidem como átomos situados fora de um contexto social [...]." (Ibid.).

Mas os atores tampouco "[...] aderem servilmente a um roteiro escrito para eles pela particular interseção de categorias sociais que ocorre de ocuparem." (GRANOVETTER, 1985, p.487, nossa tradução). Se esses ambientes registram habitus, ou subjetividade socializada - de modo que o agente social, "[...] na medida em que é dotado de um habitus, é um individual coletivo ou um coletivo 
individualizado [...]" (BOURDIEU, 1997, p.62) -, também é certo que o ator preserva a "[...] sua verdade de operador prático de construções de objeto" (BOURDIEU, 2002, p.62).

Em outras palavras, tais ambientes, com seus conteúdos socioeconômicos, culturais e institucionais, condicionam o agir dos atores, mas estes exibem espontaneidade nas suas práticas. Pode-se dizer que essa combinação permeia o debate sobre os desafios da globalização nos territórios e marca a "sociologia do lugar" nos diversos percursos socioterritoriais. No que segue, fala-se do Vale do Itajaí têxtil e do vestuário, do norte moveleiro e do oeste agroindustrial, regiões com traços socioeconômicos, culturais e institucionais que as tipificam. Os perfis foram desenhados em histórias indissociáveis das migrações europeias (notadamente a alemã e a italiana) dirigidas ao sul do Brasil no século XIX, assim como dos processos de colonização que se desenrolaram desde então.

\section{Produção têxtil e do vestuário no Vale do Itajaí}

As histórias do Vale do Itajaí e da produção têxtil e do vestuário se confundem em Santa Catarina. A ocupação da área derivou da imigração sobretudo alemã para o sul do Brasil no século XIX, e as atividades locais do complexo têxtil-vestuário são inseparáveis daquele processo, que representou a inoculação da respectiva cultura industrial no território (HERING, 1987). Empresas que depois se destacaram nacionalmente foram criadas, e outras, de vários tamanhos, se instalaram, em movimentos sucessivos de "transbordamento" durante o século XX. A cidade de Blumenau foi o epicentro dessa dinâmica.

A fabricação e comercialização desses produtos se enraizaram nesse território. Subjacente figurou uma certa história comum dos agentes, ligada à imigração e tributária de cultura fabril que representa, em si, uma instituição, expressa em condutas que valorizam o esforço individual, a disciplina no trabalho e o sucesso profissional e social. Esse padrão virou espécie de atributo regional, tanto que vários produtos têxteis locais, notadamente para cama-mesa-banho e felpudos, atingiram amplo reconhecimento em qualidade. Não erra quem refere à área como um cluster industrial, com importantes externalidades e um ativo tecido institucional, envolvendo coordenação e representação dos interesses, estruturas tecnológicas (laboratórios) e de ensino e pesquisa, e ainda serviços de apoio (LINS, 2000). 
Em especial nos anos 1990, essa estrutura foi afetada pela globalização. O acirramento da concorrência, interna e externamente, foi um aspecto maior. Despontaram no processo movimentos internacionais, das indústrias têxteis e do vestuário, que em geral resultaram em forte crescimento da participação de produtos oriundos da Ásia (muito mais baratos) nos fluxos comerciais (GEREFFI, 1999).

Também contribuíram os desdobramentos das reformas da economia brasileira, com apreciação cambial, desregulamentação e abertura comercial. Nesse quadro, o Brasil enfrentou problemas para exportar, pela concorrência de produtos asiáticos e pelos efeitos da adotada política de câmbio. Na contramão, avultou a presença de produtos estrangeiros no mercado interno, representando pressão concorrencial jamais vista até então em alguns setores, entre eles o têxtil e o de produtos do vestuário.

As empresas locais reagiram diversamente, pois a maior concorrência não significou o mesmo para todas. As maiores, e algumas de porte médio, puderam importar bens de capital (devido à taxa de câmbio e às condições oferecidas) e ampliar o uso de insumos estrangeiros, o que lhes permitiu inovar em produto e processo, incidindo em competitividade. Empresas menores, sobretudo em vestuário, menos aptas nesse sentido, tentaram evitar o embate com os importados mediante ações variadas: refúgio em nichos de mercado protegidos, aumento da qualidade e aprimoramento (design, "enobrecimento") dos produtos ou, ao contrário, rebaixamento nesses termos para reduzir custos.

Houve casos de contração produtiva e, assim, as demissões cresceram. Isso resultou também do maior uso da subcontratação ou terceirização produtiva, sobretudo por parte das empresas grandes e médias. De fato, trabalhadores demitidos passaram a atuar, até sob o estímulo dos antigos empregadores, em unidades do tipo fundo-de-quintal (facções) cujas operações voltavam-se inclusive talvez principalmente - para as empresas que antes registravam esses trabalhadores em seus quadros.

Esse foi 0 contexto em que se multiplicaram as cooperativas de trabalhadores, em regra formadas por costureiras desligadas. Tudo somado, o emprego nessas indústrias caiu, de forma brusca, na segunda metade dos anos 1990, e agravou-se a precariedade das relações de trabalho. O motivo básico é que, em numerosos casos, vínculos formais deram lugar à informalidade, com perda de direitos e aumento das adversidades e da incerteza. 
Os dados da Tabela 1 são sugestivos sobre a problemática do emprego. Construída com os registros da Relação Anual de Informações Sociais (RAIS), disponibilizados pelo Ministério da Economia, a tabela cobre o período 1994-2018 e informa sobre Santa Catarina, a Microrregião (MR) de Blumenau² - correspondente, grosso modo, ao Médio Vale do Itajaí, área de maior destaque nas indústrias têxtil e de artigos do vestuário - e o Município de Blumenau, o centro de gravidade desse espaço e desses processos. As informações descrevem o comportamento do emprego formal e indicam a participação da microrregião e do município nos totais estaduais e microrregionais, conforme a situação.

No estado como um todo, na microrregião e no município, a segunda metade dos anos 1990 - entre 1994 e 1998, especificamente - representou contração do emprego formal. Santa Catarina perdeu 15.407 desses empregos, dos quais 13.500 (88\%) na MR Blumenau e 9.909 (64\%) somente no município de Blumenau. No último, a queda foi de nada menos que $36 \%$ em apenas quatro anos. Daí em diante a tendência foi de expansão nas escalas estadual e microrregional. No município de Blumenau, a tabela aponta alcance (a rigor, ultrapassagem) do patamar do início da série só em 2008 e 2010, seguido de outra acentuação do declínio até 2018 (afetando os resultados do estado e da microrregião). Observe-se que Blumenau, apesar de seus aspectos de aglomeração industrial (externalidades, cultura fabril, instituições e outros atributos que dão sentido à palavra cluster), perdeu progressivamente participação tanto no estado como na microrregião. Isso significa ter ocorrido mudança na geografia dessas indústrias no Vale do Itajaí, com "deslocamento" principalmente para o Alto Vale, como constatado em Lins (2019) para a indústria do vestuário.

Tabela 1 - Santa Catarina, Microrregião (MR) de Blumenau e Município de Blumenau: empregos formais na produção têxtil e de artigos do vestuário e acessórios (1994-2018)

\begin{tabular}{|c|c|c|c|c|c|c|c|c|c|}
\hline \multirow{2}{*}{ Ano } & \multicolumn{2}{|c|}{ Santa Catarina } & \multicolumn{2}{|c|}{ MR Blumenau } & \multicolumn{2}{|c|}{$\begin{array}{l}\text { Município } \\
\text { Blumenau }\end{array}$} & \multirow{2}{*}{$\begin{array}{c}\mathrm{B} / \mathrm{A} \\
* \\
100\end{array}$} & \multirow{2}{*}{$\begin{array}{c}\mathrm{C} / \mathrm{A} \\
{ }^{0} \\
100\end{array}$} & \multirow{2}{*}{$\begin{array}{c}\mathrm{C} / \mathrm{B} \\
{ }^{2} \\
100\end{array}$} \\
\hline & $\begin{array}{c}\text { Empregos } \\
\text { (A) }\end{array}$ & $\begin{array}{l}\text { Ín- } \\
\text { dice }\end{array}$ & $\begin{array}{l}\text { Empregos } \\
\text { (B) }\end{array}$ & $\begin{array}{l}\text { Ín- } \\
\text { dice }\end{array}$ & $\begin{array}{l}\text { Empregos } \\
\text { (C) }\end{array}$ & $\begin{array}{l}\text { Ín- } \\
\text { dice }\end{array}$ & & & \\
\hline 1994 & 98.909 & 100 & 56.116 & 100 & 27.447 & 100 & 56,7 & 27,7 & 48,9 \\
\hline 1996 & 87.406 & 88 & 47.144 & 84 & 23.262 & 85 & 53,9 & 26,6 & 49,3 \\
\hline 1998 & 83.502 & 84 & 42.616 & 76 & 17.538 & 64 & 51,0 & 21,0 & 41,1 \\
\hline 2000 & 103.306 & 104 & 54.188 & 96 & 22.278 & 81 & 52,4 & 21,6 & 41,1 \\
\hline 2002 & 113.398 & 115 & 58.892 & 105 & 22.899 & 83 & 51,9 & 20,2 & 38,9 \\
\hline
\end{tabular}

\footnotetext{
${ }^{2}$ Em 2017 o IBGE adotou uma nova regionalização: regiões geográficas intermediárias e regiões geográficas imediatas, em substituição às mesorregiões e às microrregiões, nessa ordem (cf. Divisão..., 2017). A composição não é necessariamente a mesma, mas os recortes coincidem em grande parte. A RAIS continuou a utilizar a regionalização anterior, o que permite comparar períodos diferentes.
} 


\begin{tabular}{rrrrrrrrrr}
2004 & 124.059 & 125 & 63.787 & 114 & 23.316 & 85 & 51,4 & 18,8 & 36,5 \\
2006 & 139.754 & 141 & 72.372 & 129 & 26.513 & 97 & 51,8 & 19,0 & 36,6 \\
2008 & 154.880 & 157 & 79.142 & 141 & 30.041 & 109 & 51,1 & 19,4 & 38,0 \\
2010 & 173.240 & 175 & 82.955 & 148 & 31.185 & 114 & 47,9 & 18,0 & 37,6 \\
2012 & 166.730 & 169 & 78.878 & 141 & 26.643 & 97 & 47,3 & 16,0 & 33,8 \\
2014 & 173.676 & 176 & 78.361 & 140 & 25.149 & 92 & 45,1 & 14,5 & 32,1 \\
2016 & 160.788 & 163 & 73.099 & 130 & 23.155 & 84 & 45,5 & 14,4 & 31,7 \\
2018 & 160.119 & 162 & 72.066 & 128 & 21.785 & 79 & 45,0 & 13,6 & 30,2 \\
\hline
\end{tabular}

Fonte: elaborado pelo autor com dados da RAIS (S.d.)

Obs.: os dados referem-se à agregação entre a Divisão 17 - Fabricação de produtos têxteis e a Divisão 18 - Confecção de artigos do vestuário e acessórios, da CNAE 95 (cf. CONCLA, 2002); tratase dos vínculos ativos em $31 / 12$ de cada ano

\section{Uma rarefeita cultura de vínculos sociais}

Em face das novas condições, prevaleceu entre as empresas o "diálogo" próprio, individual, com as pressões da globalização. Rivalidade e individualismo se destacaram, não obstante a prática recorrente, entre os empresários, de encontros para discutir assuntos da conjuntura e de empréstimos de materiais e máquinas para aqueles em situação momentaneamente problemática, no que configuraria uma cooperação de boa vizinhança.

A rigor, "[...] pouco se coopera localmente, praticamente inexistindo parcerias ou alianças estratégicas voltadas à produção, à comercialização e às relações com fornecedores" (LINS, 2008, p.376). Observe-se que a própria natureza desses setores, em que diferenciar produtos é essencial, desestimula esse tipo de relação entre concorrentes. Ao mesmo tempo, porém, o individualismo exacerbado e o espírito de autossuficiência contribuem para amplificar as dificuldades para realizações nesse sentido, algo que diz respeito principalmente às empresas maiores e mais tradicionais.

A fragilidade e limitação das ações conjuntas poderiam surpreender quem imaginasse que, pelas histórias e experiências compartilhadas por boa parte dos agentes no enfrentamento dos percalços da colonização - sem dúvida exigentes de espírito de reciprocidade, solidariedade e colaboração apto a resultar em "cimento" comunitário -, as adversidades contemporâneas seriam encaradas coletivamente, sob confiança mútua. Apesar de atuarem em ambiente com esses traços socioculturais e institucionais, os agentes geralmente se conduziram norteados pelo sentido de competição - encarniçada e não raro predatória -, em vez de pela ideia de comportamento coletivo e cooperativo (LINS, 2000).

As instituições de coordenação e representação dos produtores formam esfera em que algumas ações coletivas foram protagonizadas. Interessando tais iniciativas mormente às empresas menores, tratou-se nesses casos de busca de 
informações sobre procedimentos para a promoção local no exterior, para avanços em infraestrutura tecnológica, para formação de recursos humanos e para realização de eventos como feiras e mostras.

Fora desse âmbito, quase nada se observa, pois as empresas, como já sugerido, pouco cooperam por conta própria. Seja como for, os efeitos locais da globalização abarcariam, além da maior polarização entre empresas de portes diferentes - com as grandes ampliando o seu peso na hierarquia dos negócios -, recuo em quadro socioprofissional antes marcado por volumoso emprego formal. Essa contração ganhou novo ímpeto nos últimos anos, principalmente desde 2014, como se pode observar na Tabela 1. Os reflexos dessa intensificação em escala de região, seja nas condições de trabalho ou nos termos de reprodução social, não parecem carecer de profundidade (FREITAG; BRANDÃO, 2018).

\section{Produção moveleira no norte catarinense}

Erva mate e madeira eram os produtos básicos do norte catarinense no século XIX. Com a chegada de migrantes europeus - alemães, austríacos e poloneses, segundo Ficker (1973) - desde os anos 1870, a abundância de recursos florestais ensejou negócios familiares na forma de marcenarias, notadamente. Circunstâncias impulsionaram o envolvimento com a produção de artefatos de madeira e móveis (rústicos) para uso local, assim como de insumos para a construção civil. O segmento de móveis ganhou vigor desde os anos 1940, surgindo empresas que depois se destacaram na região e mesmo no país. Experiências individuais foram desbravadoras no início do século $\mathrm{XX}$, como a que ganhou fama sob a razão social Móveis CIMO S.A, no Município de Rio Negrinho (LINS; SOUSA, 2014).

Interações com fabricantes e instituições em outros lugares, até na Europa, contemplando capacitação técnica e design, tiveram importância em certos casos. Grupos industriais foram surgindo até os anos 1980, e o crescimento do setor se intensificou. Naquela década, mudanças no mercado interno, em boa parte ligadas ao adverso quadro econômico brasileiro e à substituição da madeira até então utilizada, provocaram reestruturação produtiva e atualização tecnológica que nutriram viés exportador, consolidada nos anos 1990 (DENK; CARIO, 2002). 
Assim, sobretudo nos municípios de São Bento do Sul e Rio Negrinho, numerosos produtores (a maioria de menor porte) vieram a formar tecido produtivo no qual firmas especializadas em segmentos dos processos produtivos favoreciam a divisão técnica do trabalho mediante subcontratação ou terceirização (LANZER; CASAROTTO Fo; CUNHA, 1998). A área igualmente passou a registrar a atuação de instituições de representação e coordenação dos interesses do setor, de ensino e pesquisa e de cunho tecnológico, além de outros serviços. Um cluster moveleiro adquiriu, assim, forma no norte catarinense, com expressivo desempenho exportador.

A base das vendas ao exterior eram as encomendas de lojistas instalados nos Estados Unidos e na Europa. Esses clientes definiam todos os parâmetros (design, matéria prima, insumos, preço, prazo) e os determinavam aos fabricantes (principalmente empresas grandes e médias). Isso ocorria por meio de agentes de exportação, cujo papel sempre foi importante também pelo que tais profissionais representavam no tocante à difusão local de conhecimentos. Os resultados das exportações, que para alguns fabricantes, segundo Denk (2002), chegaram a representar quase todo o faturamento, estimularam o aprofundamento da orientação externa sob o comando dos clientes estrangeiros, interessados principalmente em móveis para dormitórios, cozinhas, salas e escritórios.

Aceitar prazo, preço e design assegurava a permanência de fabricantes locais nesses vínculos externos. Contudo, os produtores participavam desse comércio de modo subordinado, como quase reféns das decisões dos compradores. À primeira vista, lograr upgrade em tais relações, galgando degraus rumo à condição de, por exemplo, detentores de design próprio, deveria representar objetivo estratégico na área. Porém, pesquisa de campo explorada em Comerlatto e Lins (2008) mostrou empresas satisfeitas com aquela forma de internacionalização. Algumas sequer cogitavam sobre desenvolver design e prospectar mercados por sua conta, argumentando que essa direção representaria custos elevados e risco de perda das encomendas de clientes tradicionais. É sugestivo que na tentativa, ao final dos anos 1990, de implementar na região o Programa Brasileiro de Incremento às Exportações de Móveis (PROMÓVEL), destinado a capacitar as empresas à exportação (agregando valor aos produtos), tenha sido mínimo o interesse local pelo módulo referente ao design próprio (LINS; GUIMARÃES, 2008). 
A segunda metade da primeira década do presente século testemunhou uma inflexão nas condições de funcionamento do aglomerado moveleiro do norte de Santa Catarina. De 2005 em diante, as exportações trilharam caminho de continuado declínio, a reboque da apreciação relativa da moeda brasileira e do acirramento da concorrência internacional. Em relação ao segundo aspecto, cabe referência particular ao comportamento da China, que já na virada do século figurava em $2^{\circ}$ lugar no ranking dos exportadores de móveis, como observaram Kaplinsky et al. (2003) em pesquisa sobre a chamada cadeia de valor global dos móveis de madeira. A proeminência do país asiático não arrefeceu, embalada por trajetória produtiva ao longo da qual, por exemplo, a participação chinesa na produção moveleira mundial saltou de 17\% para 36\% entre 2007 e 2012 (CARIO et al., 2013).

Agregou traços ainda mais fortes às circunstâncias então vivenciadas, o espraiamento dos efeitos da aguda crise decorrente do estouro da bolha imobiliária nos Estados Unidos em 2008. O consumo dos produtos de diferentes cadeias produtivas foi duramente afetado, com reflexos nas vendas, e isso acirrou a disputa competitiva por fatias do mercado em nível mundial. Assinale-se que esse processo foi antevisto, e captado nos seus impulsos iniciais, por diferentes estudos editados em Cattaneo, Gereffi e Staritz (2010).

Dependente do desempenho exportador, a indústria moveleira do norte catarinense não passou incólume pelos processos e turbulências na esfera mundial. Ao contrário, o abalo nas exportações, sobretudo por conta da baixa taxa de câmbio, teve importantes efeitos locais. Contribuiu o fato de a tentada reorientação produtiva para ampliar a presença no mercado doméstico, intensificada desde 2013, ter se deparado com a dificuldade adicional representada pela concorrência de fabricantes de outros estados (paulistas, gaúchos, mineiros), já bem posicionados.

Para produtores cujo faturamento era todo ou quase todo vinculado às exportações, voltar-se para esse mercado implicava readequação dos processos de fabricação. O grau de sucesso foi variado, com casos de paulatino e demorado avanço e outros de fechamento do negócio, pura e simplesmente, em empresas de diferentes tamanhos. A mídia local não deixou de registrar algumas das situações contrastadas, como ilustrado pela reportagem de A Notícia em 4 de abril de 2014 (POLO..., 2014).

O setor moveleiro local parece ter se deixado aprisionar na comodidade de exportações sob o completo comando de clientes estrangeiros. Quando a situação 
do mercado mudou, o bom desempenho anterior teria se refletido numa certa inércia nas estruturas locais. Os resultados preocuparam, pois houve encerramento de atividades em algumas empresas ou, pelo menos, grande atrofia. Naturalmente, a histórica presença de subcontratação ou terceirização produtiva no seio do sistema local tornou inevitáveis as repercussões no território, refletindo-se particularmente no emprego.

A Tabela 2 é sugestiva sobre essas consequências. Construída com dados da RAIS, informando, portanto, sobre vínculos formais de trabalho, a tabela recobre a Microrregião (MR) de São Bento do sul (formada pelo respectivo município e pelos de Campo Alegre e Rio Negrinho) no período de 1994 a 2018, bianualmente.

Tabela 2 - Santa Catarina e Microrregião de São Bento do Sul: empregos formais na produção de móveis (1994-2018)

\begin{tabular}{|c|c|c|c|c|c|}
\hline \multirow[b]{2}{*}{ Ano } & \multicolumn{2}{|c|}{ Santa Catarina } & \multicolumn{2}{|c|}{$\begin{array}{l}\text { Microrregião S. Bento do } \\
\text { Sul }\end{array}$} & \multirow[t]{2}{*}{$B / A * 100$} \\
\hline & $\begin{array}{l}\text { Empregos } \\
\text { (A) }\end{array}$ & İndice & $\begin{array}{l}\text { Empregos } \\
\text { (B) }\end{array}$ & İndice & \\
\hline 1994 & 18.997 & 100 & 9.408 & 100 & 49,5 \\
\hline 1996 & 19.636 & 103 & 8.545 & 91 & 43,5 \\
\hline 1998 & 19.665 & 103 & 7.977 & 85 & 40,6 \\
\hline 2000 & 26.065 & 137 & 9.643 & 102 & 37,0 \\
\hline 2002 & 28.211 & 148 & 10.702 & 114 & 37,9 \\
\hline 2004 & 32.273 & 170 & 12.303 & 131 & 38,1 \\
\hline 2006 & 28.779 & 151 & 11.465 & 122 & 39,8 \\
\hline 2008 & 26.380 & 139 & 9.219 & 98 & 34,9 \\
\hline 2010 & 27.489 & 145 & 8.140 & 86 & 29,6 \\
\hline 2012 & 28.600 & 150 & 7.496 & 80 & 26,2 \\
\hline 2014 & 30.155 & 159 & 7.532 & 80 & 25,0 \\
\hline 2016 & 27.779 & 146 & 7.433 & 79 & 26,8 \\
\hline 2018 & 28.406 & 149 & 7.041 & 75 & 24,8 \\
\hline
\end{tabular}

Fonte: elaborado pelo autor com dados da RAIS (S.d.)

Obs.: os dados referem-se ao Grupo 36.1 - Fabricação de artigos do mobiliário, da CNAE 95 (cf. CONCLA, 2002); trata-se dos vínculos ativos em 31/12 de cada ano

Os números sobre a região são eloquentes. A tendência de expansão até 2004 foi substituída pela de um acentuado e linear declínio desde então, mostrandose o contingente do último ano da série $25 \%$ inferior ao da abertura. Concomitantemente desenrolou-se persistente contração da presença regional nos totais catarinenses: em 1994, a região concentrava cerca de metade dos empregos formais da produção moveleira estadual; em 2018, a participação foi menor do que 1/4. A queda espelha tanto a própria retração local dessa indústria quanto o seu 
importante crescimento em outras áreas do estado, notadamente no oeste catarinense, nas microrregiões de Chapecó e São Miguel do Oeste (LINS, 2017).

\section{Dificuldades para ações coletivas}

A situação imposta a esse cluster moveleiro pelos movimentos enfeixados na globalização exigiria o aprimoramento do desempenho exportador em nível local, algo que o mencionado PROMÓVEL vislumbrava. Para tanto, a experiência internacional sugere serem estratégicas a organização e a atuação de grupos de empresas em torno de, entre outros: programas e ações coletivos; elevação conjunta dos níveis de qualidade e competitividade; prospecção de novos mercados por meio de missões empresariais e de participação em eventos como feiras.

Poder-se-ia esperar que a herança sociocultural mais ou menos comum dos agentes locais - tendo-se em vista, em primeiro lugar, os fabricantes - lubrificasse interações nesse sentido no norte moveleiro de Santa Catarina, como visto em experiências repertoriadas na literatura internacional. Todavia, segundo Denk (2002), constitui destacado traço local a presença de um baixo grau de associativismo, a ponto de se admitir ser "[...] necessária a promoção de esforços no sentido de diminuir o espírito de competição destruidora." (SEABRA; PAULA; FORMAGGI, 2008, p. 291).

Cooperação na área, ainda que escassa, rarefeita e informal, envolveria tão somente empresas de menor porte, registrando-se a esse respeito algum apoio institucional. Interações efetivas com fornecedores não significam muito mais do que, por exemplo, trocas de informações sobre desempenho de produtos. São raras as ações conjuntas em melhorias técnicas, projetos e utilização de maquinário ou laboratórios, em processos de compartilhamento de novas possibilidades com vistas ao avanço coletivo em competitividade (DENK, 2002).

Com efeito, pelo que tudo leva a crer, pode-se dizer que prevalece na principal área de produção de móveis em Santa Catarina a atuação isolada das empresas, sem palpável incidência de condutas férteis para permutas de experiências e conhecimentos. Isso seria sinônimo de um enraizado espírito de individualismo, provavelmente propício a comportamentos norteados muito mais pela rivalidade do que pela tentativa de descortinar alternativas coletivamente diante das dificuldades. 
Reitere-se que esse cenário de interações pobres prevaleceria especialmente entre as maiores empresas. As menores, como assinalado por Seabra, Paula e Formaggi (2008), entre outros, costumam atribuir importância à cooperação, mesmo que suas ações com tais características não transcendam aspectos de, comparativamente, menor relevância na promoção da competitividade (apenas aspectos como, entre possíveis outros, empréstimos de materiais, negociações sindicais e organização de eventos).

\section{Produção agroindustrial de carnes no oeste catarinense}

O região oeste foi a última a ser colonizada em Santa Catarina. Entre seus protagonistas sobressaíram descendentes de imigrantes alemães e italianos antes fixados no Rio Grande do Sul. A partir dos anos 1910, vários núcleos de ocupação foram criados, instalando-se processo que geraria a presente estrutura socioespacial (PAIM, 2006; SILVA; ROSA, 2010). Essa colonização foi a base da orientação produtiva da região, ligada principalmente à agroindústria de carnes. A suinocultura, com processamento da carne, passou de prática tradicional em pequenas propriedades rurais familiares para atividade de grande e crescente importância econômica no plano regional (TESTA et al., 1996).

Foi decisiva a adoção do modelo de integração "colono-frigorífico", traduzido na atuação de estruturas industriais escoradas em interações entre proprietários rurais encarregados de criar os animais e empresas de abate e processamento. Esses vínculos são formalizados por contratos, esfera em que se definem e estipulam os aspectos do modus operandi a ser observado pelos produtores na lide da criação, além de outros aspectos da parceria (COLLETI; LINS, 2011).

A partir dos anos 1960, a avicultura e a industrialização das respectivas carnes adentraram o cenário regional. Sua escalada, rumo a patamar representativo de setor chave na economia da região e do estado, exibiu desde os primeiros passos a presença do sistema de integração, com a indústria em posição de completo controle de todo o processo produtivo, transferindo às propriedades rurais, praticamente, os riscos da criação (LAZZARI, 2004). Como na suinocultura, a independência dos produtores rurais é apenas formal na avicultura.

A criação de suínos e aves e o processamento de carnes tornaram-se pilares da economia regional, que tem em Chapecó a maior cidade de um grande território com numerosos municípios majoritariamente rurais. A região sobressai no estado, indiscutivelmente, na geografia da produção de suínos e aves para abate, como 
permite observar a Figura 1, cujas informações referem-se a 2017. O oeste catarinense responde pela proeminência nacional de Santa Catarina tanto na produção de carnes de suínos e aves quanto nas exportações dos produtos relacionados (LINS, 2018).

Figura 1 - Santa Catarina: geografia da produção de suínos e frangos para abate em 2017

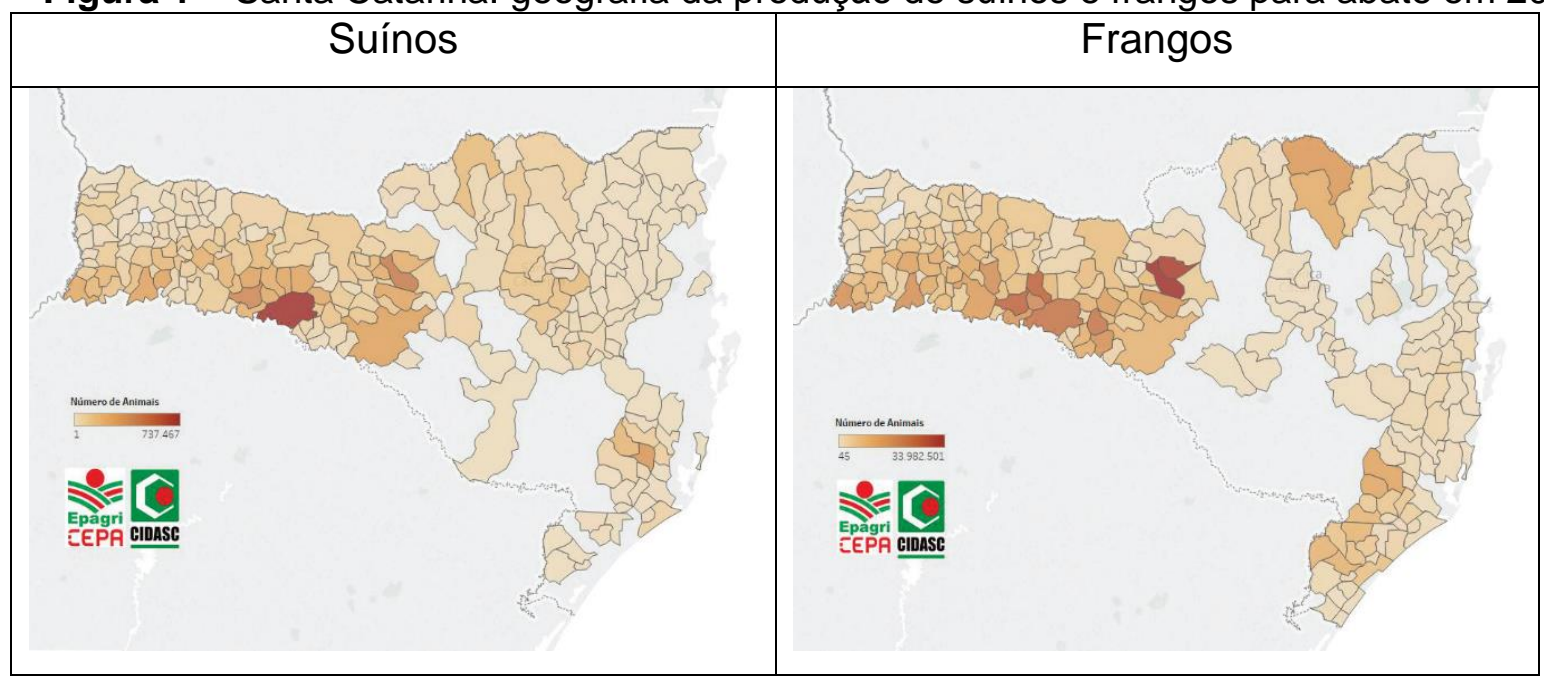

Fonte: Governo de Santa Catarina (2019); p. 149 para suínos e p. 137 para frangos

Além de empresas industriais e produtores rurais, a área abriga instituições diversas, em coordenação e representação dos interesses do setor agroindustrial e em ensino e pesquisa relacionados (também envolvendo tecnologia), assim como serviços de apoio. Organismos de promoção do desenvolvimento local, de abrangência espacial variada, interagem com representantes na região de estruturas integrantes do aparato governamental (estadual, federal) voltado ao meio rural. Em torno das atividades principais, apoiando o seu desempenho ou usufruindo do estímulo emanado, vicejaram outros setores, como de embalagens e transportes.

Assim, falar em cluster agroindustrial escorado na suinocultura e na avicultura não constitui equívoco. Além de tudo, o território registra uma cultura rural enraizada em décadas de experiência histórica compartilhada por numerosos contingentes. Instituições como a Igreja tiveram importância no percurso, suas atividades em distritos rurais dos diferentes municípios cevando vínculos sociais em escala comunitária e promovendo ajuda mútua e comportamentos baseados em solidariedade e reciprocidade. Mutirões e outras práticas coletivas, frequentes entre os primeiros ocupantes da região, foram assim preservadas e estimuladas (POLI, 2002). 
Os atributos do território, formados em trajetória de décadas, mostraram-se importantes perante os desafios da globalização. Estes expressaram-se em aumento da concorrência nos mercados internos por conta da entrada vigorosa, desde os anos 1990, de interesses agroindustriais estrangeiros no Brasil. O mesmo se deu nos mercados externos, ao lado da ampliação das exigências em qualidade e diversidade de produtos, indissociáveis de mudanças nos hábitos alimentares e no comportamento dos consumidores, de um modo geral.

Em face das pressões, a esfera do processamento na cadeia agroindustrial intensificou as imposições sobre a esfera rural, exigindo mais investimentos em equipamentos, animais e tecnologia, entre outros (COLLETTI; LINS, 2011). Miravase a produtividade e a qualidade, enquanto na órbita industrial, realçando a oferta de novas opções alimentares, avançava-se na diversificação de produtos em conexão com os movimentos na esfera do consumo. Também houve investimentos de empresas locais, ou que atuavam na região, em novas capacidades de processamento fora do oeste catarinense, como no Centro-Oeste do Brasil. Isso traduzia sensibilidade à dinâmica em curso junto a atividades centrais da cadeia produtiva, como o cultivo de grãos, insumos básicos na fabricação de ração, que tem destaque nos custos da criação (HELFAND; REZENDE, 1999).

Em geral, as repercussões no oeste catarinense foram intensas. Tendo como pano de fundo um declínio persistente no estado, desde meados dos anos 1980, dos contingentes ocupados nos estabelecimentos agropecuários e da quantidade destes, como indicado em Ferrari et al. (2019), caiu o número de propriedades rurais integradas à agroindústria, um processo detectado especialmente na década de 1990. As empresas processadores de carnes optaram por manter nos vínculos de integração somente os produtores mais capazes de investir e representativos, devido à localização, de vantagens logísticas.

Paralelamente, cresceu a concentração na suinocultura e na avicultura, e ganharam intensidade as relações que reverberavam longe da região por conta dos aludidos investimentos extra locais. De algum modo, todo esse processo transparece nos dados dos censos agropecuários das últimas décadas, sobre a distribuição dos efetivos de suínos e aves conforme o tamanho das propriedades rurais, objeto da Tabela 3. Assinale-se que, como o IBGE mudou em 2017 a divisão regional brasileira, substituindo mesorregiões e microrregiões por regiões geográficas intermediárias e regiões geográficas imediatas, a tabela presta-se mais à comparação dos percentuais do que dos números absolutos, ao longo do tempo. 
Nota-se que, em suínos, caiu a participação do efetivo nas propriedades com área inferior a 20 ha, entre os censos agropecuários de 1995 e 2017, e cresceu, quase dobrando, aquela referente às propriedades de 100 ha e mais. Em aves, os efetivos das propriedades rurais com área inferior a 20 ha perderam presença expressivamente entre os censos agropecuários de 1995 e 2006: recuo de 45\% do total de cabeças para 39\%, em benefício das propriedades com área entre 20 ha e menos de 50 ha, cuja participação cresceu dez pontos percentuais. Mas daí até o censo de 2017, aquela faixa de propriedades menores ganhou terreno na avicultura, suplantando a sua presença inicial: nesse ano, $53 \%$ dos efetivos diziam respeito às propriedades com área inferior a $20 \mathrm{ha}$, aparentemente indicando que o processo de concentração na avicultura teria sofrido reversão (mas seria necessário aprofundar o estudo para uma ideia mais clara sobre isso, o que está fora dos objetivos deste artigo).

As mudanças na agroindústria parecem ter afetado a dinâmica demográfica. Dados compilados em Lins (2017) mostram que entre os censos demográficos de 1991 e 2010 a participação da população total da Mesorregião Oeste Catarinense no conjunto de Santa Catarina caiu de $23 \%$ para $19 \%$. O recuo foi ainda maior na população rural, com o oeste perdendo cinco pontos percentuais na representatividade estadual. Assim, caberia falar, de certo modo, em desruralização. Embora heterogêneo, tal processo transparece, por exemplo, na contração da população rural de $49 \%$ para $28 \%$ do total populacional entre aqueles censos demográficos, na mesorregião como um todo.

Tabela 3 - Oeste catarinense: efetivos dos rebanhos de suínos e aves por grupos de área total das propriedades rurais - mil cabeças (1995-2017)

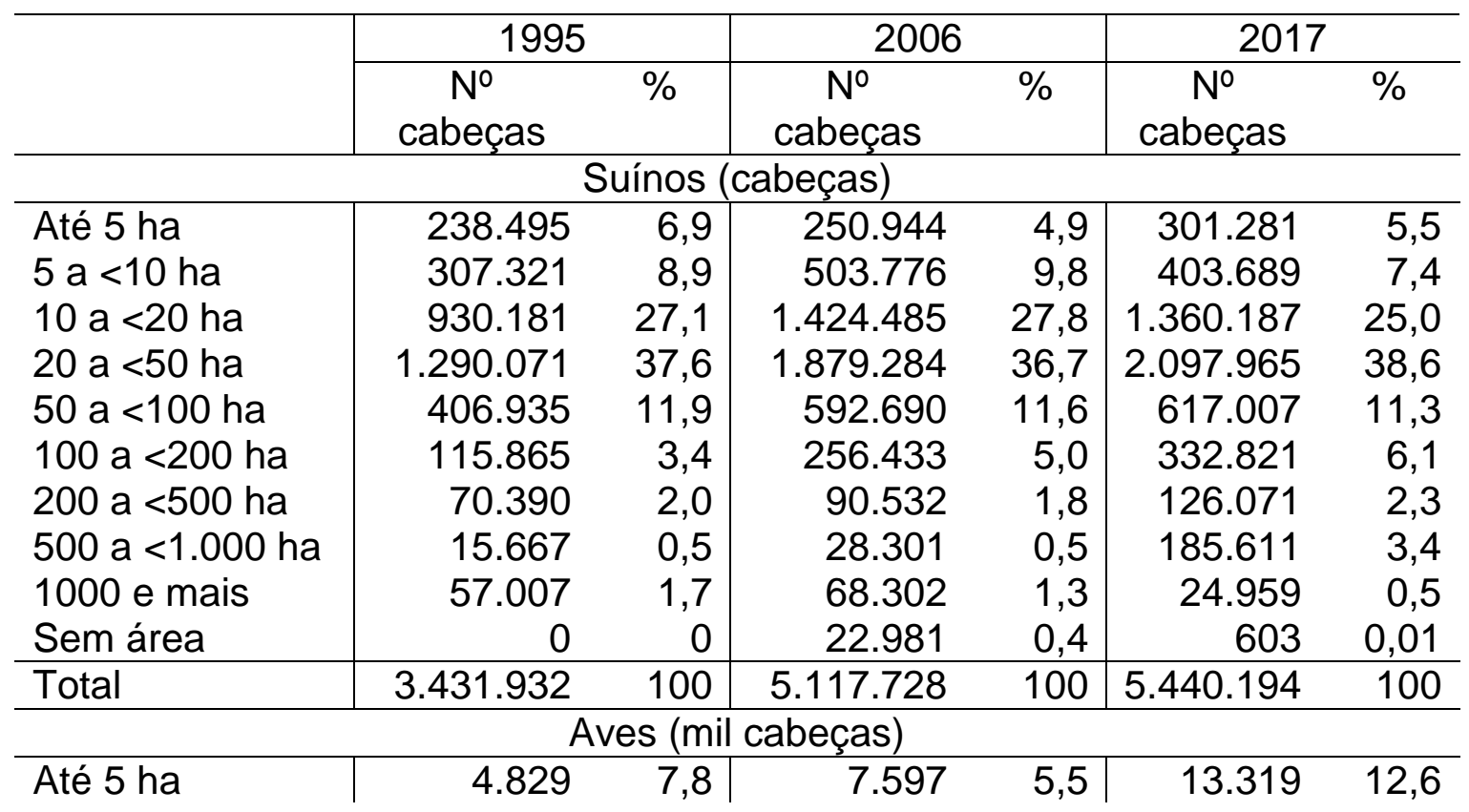




\begin{tabular}{l|rr|rr|rr}
$5 \mathrm{a}<10$ ha & 6.434 & 10,4 & 13.401 & 9,8 & 12.924 & 12,2 \\
$10 \mathrm{a}<20$ ha & 16.747 & 27,1 & 32.820 & 23,9 & 30.076 & 28,4 \\
$20 \mathrm{a}<50$ ha & 22.552 & 36,5 & 64.730 & 47,2 & 36.418 & 34,4 \\
$50 \mathrm{a}<100 \mathrm{ha}$ & 6.746 & 10,9 & 11.095 & 8,1 & 10.675 & 10,1 \\
$100 \mathrm{a}<200 \mathrm{ha}$ & 2.489 & 4,0 & 3.062 & 2,2 & 3.914 & 3,7 \\
$200 \mathrm{a}<500$ ha & 963 & 1,6 & 2.245 & 1,6 & 1.287 & 1,2 \\
$500 \mathrm{a}<1.000$ ha & 388 & 0,6 & 276 & 0,2 & 965 & 0,9 \\
1000 e mais & 656 & 1,1 & 846 & 0,6 & 140 & 0,1 \\
Sem área & 0 & 0 & 1.155 & 0,8 & 1 & 0 \\
\hline Total & 61.804 & 100 & 137.227 & 100 & 105.919 & 100 \\
\hline
\end{tabular}

Fonte: elaborado pelo autor com dados de IBGE $(1996 ; 2006 ; 2017)$

Obs.: a) os dados para 1995 referem-se ao total de aves; em 2006 e 2017, trata-se de galinhas, galos, frangas, frangos e pintos; b) em 1995 e 2006, o recorte geográfico é a Mesorregião Oeste Catarinense, do IBGE; em 2017, trata-se da Região Geográfica Intermediária Chapecó; a correspondência entre ambas não é total

Movimentos migratórios foram cevados nesse contexto, também com diferenças entre as microrregiões. Estudo elaborado por Silva et al. (2003) detectou que, em alguns casos, a perda de população rural foi compensada pelo crescimento da população urbana, traduzindo movimentos campo-cidade de pequena amplitude e a absorção, de algum modo, daqueles contingentes pela economia citadina, sobretudo nas microrregiões de Chapecó e Joaçaba. Em outras, notadamente na de São Miguel do Oeste, a desruralização mostrou-se persistente desde os anos 1980, com intensificação nos 1990. Aliás, essa microrregião apresentou expressiva redução na sua participação no conjunto da Mesorregião Oeste Catarinense: entre 1991 e 2010, sua população total passou de 18\% para 14\% relativamente à mesorregião.

\section{Iniciativas locais diante das adversidades}

As possibilidades de reprodução social foram afetadas no oeste catarinense, em particular nas áreas rurais, dando corpo à ideia de crise regional (THEIS; NODARI, 2000). Uma reposta foi o abandono de áreas rurais, com aumento das migrações rumo às maiores cidades da região e alhures, fazendo encolher a população em vários municípios, como já indicado. Mas não foi somente isso que se observou. Outro tipo de reação, denotando capacidade de articulação e voluntarismo entre atores locais, resultou em multiplicação de pequenas agroindústrias rurais familiares e redes de cooperação, com associações, condomínios e cooperativas envolvendo famílias atingidas pela reestruturação agroindustrial (MARCONDES et al., 2012). 
Apoiado por serviços de extensão rural e instituições regionais, esse processo exibiu aspectos de reciprocidade e cooperação cujas raízes remontam às experiências e histórias compartilhadas em duradouras relações de vizinhança e ajuda mútua (MIOR, 2005). Estabelecidos em percurso de muitas décadas, e vinculados à ruralidade que marca o oeste catarinense, esses atributos teriam aflorado e produzido desdobramentos diante das adversidades, em condutas amplamente emanadas da base social da região.

A Tabela 4 registra situação de 2010 relativamente a esse processo. Salta aos olhos que a região oeste apresentava inegável destaque em escala catarinense quanto à presença de agroindústrias rurais familiares e redes de cooperação, nas diversas formas de manifestação destas.

A Tabela 5, elaborada com dados do Censo Agropecuário de 2017, atualiza e amplia aquela visão. Os estabelecimentos agropecuários com agroindústria rural, instalados na Região Geográfica Intermediária Chapecó, representavam quase 3/4 do equivalente estadual, uma participação que se mostrava ainda maior para os estabelecimentos com agricultura familiar. Era também elevada a expressão do oeste catarinense em termos de valor da produção da agroindústria rural: a região representava pouco menos da metade do agregado estadual para o total de estabelecimentos, e 54\% para aqueles com agricultura familiar.

Tabela 4 - Santa Catarina e oeste catarinense: agroindústrias rurais familiares e redes de cooperação (associações, condomínios e cooperativas) (2010)

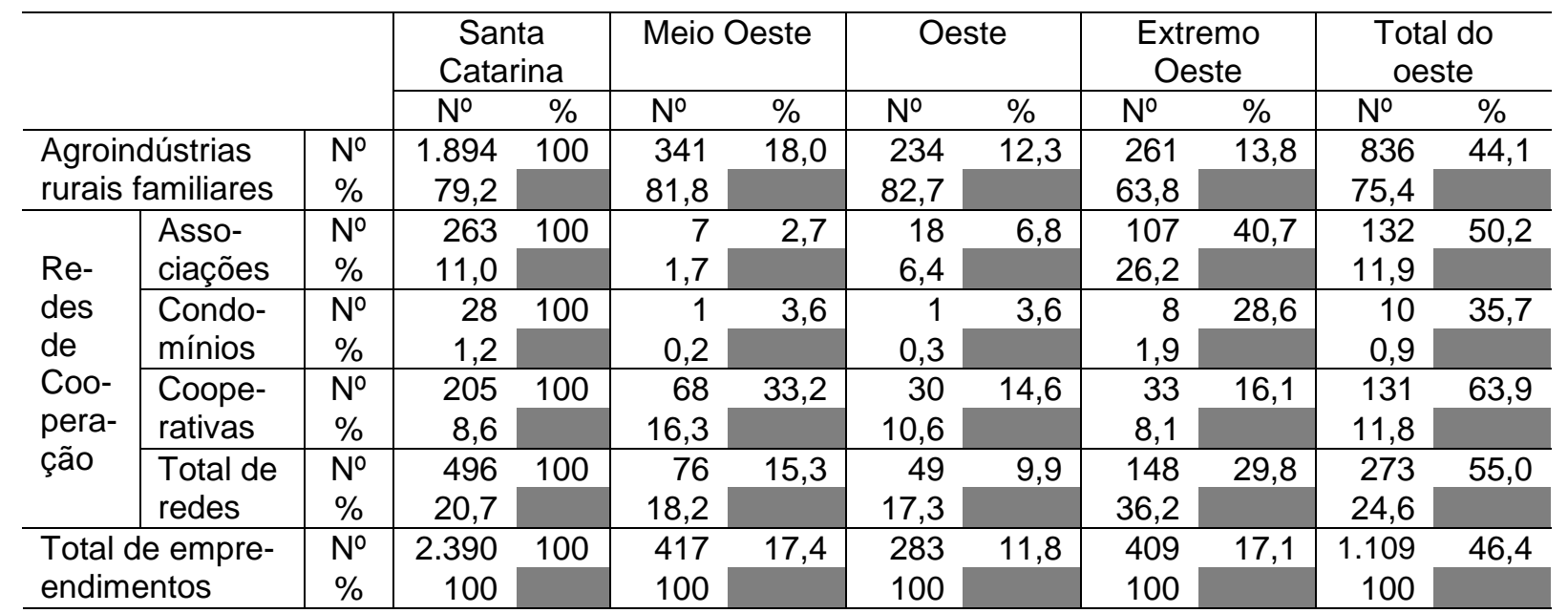

Fonte: Marcondes et al., (2012), p. 7 e 27

Obs.: A divisão região do oeste catarinense refere-se às Unidades de Gestão Técnica (UGT) da EPAGRI: UGT 1: Oeste Catarinense, UGT 2: Meio Oeste Catarinense, UGT 9: Extremo-Oeste Catarinense

Tabela 5 - Santa Catarina e Região Geográfica Intermediária (RGI) Chapecó: número de estabelecimentos e valor da produção da agroindústria rural (2017) 


\begin{tabular}{|c|c|c|c|c|}
\hline & & Total & $\begin{array}{c}\text { Sem agricultura } \\
\text { familiar }\end{array}$ & $\begin{array}{c}\text { Com agricultura } \\
\text { familiar }\end{array}$ \\
\hline \multicolumn{5}{|c|}{ Estabelecimentos agropecuários com agroindústria rural } \\
\hline $\begin{array}{l}\text { Santa } \\
\text { Catarina }\end{array}$ & $\begin{array}{l}\text { № de estabelecim. } \\
\%\end{array}$ & $\begin{array}{rr} & 96.334 \\
{[100]} & (100)\end{array}$ & $\begin{array}{rr} & 11.282 \\
{[11,7]} & (100) \\
\end{array}$ & $\begin{array}{rr} & 85.052 \\
{[88,3]} & (100) \\
\end{array}$ \\
\hline $\begin{array}{l}\text { RGI } \\
\text { Chapecó }\end{array}$ & $\begin{array}{l}\text { № de estabelecim. } \\
\%\end{array}$ & $\begin{array}{rr} & 70.882 \\
{[100]} & (73,6) \\
\end{array}$ & $\begin{array}{ll} & 6.508 \\
{[9,2]} & (57,7) \\
\end{array}$ & $\begin{array}{rr} & 64.374 \\
{[90,8]} & (75,7) \\
\end{array}$ \\
\hline \multicolumn{5}{|c|}{ Valor da produção da agroindústria rural } \\
\hline $\begin{array}{l}\text { Santa } \\
\text { Catarina }\end{array}$ & $\begin{array}{l}\text { Mil Reais } \\
\%\end{array}$ & $\begin{array}{rr}413.880 \\
{[100]} & (100) \\
\end{array}$ & $\begin{array}{rr}109.745 \\
{[26,5]} & (100) \\
\end{array}$ & \begin{tabular}{rr}
\multicolumn{2}{r}{304.126} \\
{$[73,5] \quad(100)$} \\
\end{tabular} \\
\hline $\begin{array}{l}\text { RGI } \\
\text { Chapecó }\end{array}$ & $\begin{array}{l}\text { Mil Reais } \\
\%\end{array}$ & $\begin{array}{rr} & 197.017 \\
{[100]} & (47,6) \\
\end{array}$ & $\begin{array}{rr} & 32.866 \\
{[16,7]} & (29,9) \\
\end{array}$ & $\begin{array}{rr} & 164.142 \\
{[83,3]} & (54,0) \\
\end{array}$ \\
\hline
\end{tabular}

Fonte: elaborado pelo autor com dados de IBGE (2017)

\section{Atributos territoriais e reações locais: uma breve discussão}

Em Santa Catarina, o Vale do Itajaí têxtil e do vestuário, o norte moveleiro e o oeste agroindustrial sofreram os efeitos da globalização notadamente desde os anos 1990. Tais consequências se traduziram, por exemplo, em forte intensificação da concorrência no mercado interno e também no exterior.

Exibindo "culturas econômicas" específicas, as referidas regiões possuem estoques de externalidades formados durante suas trajetórias setoriais, e boa parte dos atores locais compartilha histórias, experiências e traços socioculturais mais ou menos próprios, o todo representado amálgama que poderia canalizar condutas permeadas do sentido de vínculo social. Perante os desafios, isso encorajaria e sustentaria - assim sugere a literatura - ações conjuntas e colaborativas com resultados nos planos individual e coletivo. Contudo, foram diferentes as situações observadas nesses territórios.

No Vale do Itajaí, prevaleceram os comportamentos individuais, em geral nas grandes empresas. Estas e algumas empresas médias aproveitaram as facilidades para importar e avançaram em modernização e reestruturação, o que representou, ao menos nos anos 1990, forte redução do emprego e aumento da subcontratação ou terceirização. Entre as menores empresas, várias enfrentaram dificuldades causadoras de atrofia ou mesmo desativação de atividades. Em meio a exacerbados individualismo, rivalidade e até competição desleal, embora ocorresse - sob estímulo institucional - alguma cooperação nos segmentos das pequenas e médias empresas (em aspectos secundários), os processos assimilados à globalização reverberaram, pelo menos por alguns anos, em regressão no mundo do trabalho: aumentou a precariedade e cresceram as dificuldades para a reprodução social de expressivos contingentes. 
No norte moveleiro, a piora nas vendas externas por conta, em boa medida, da invasão de móveis chineses no mercado mundial e da situação cambial, atingiu empresas exportadoras e atividades a elas relacionadas. Dependentes dessas vendas e acomodadas em sistema no qual os clientes definiam os parâmetros produtivos, essas empresas tentaram se voltar para o mercado brasileiro, enfrentando concorrentes nacionais melhor posicionados, em empreitada que exibiu resultados heterogêneos. Lidar com adversidades para exportar inclui a necessidade de articular as empresas em torno de objetivos comuns, o que demanda cooperação e práticas coletivas. Ora, a região sofre de baixo grau de associativismo entre os fabricantes: as poucas ações com esse perfil não ostentam muito mais do que escassos efeitos, como trocas de informações com fornecedores e empréstimos de materiais entre produtores.

No oeste agroindustrial, a reestruturação no beneficiamento de carnes abrangeu a redução dos contingentes de produtores rurais integrados em criação de animais, assim como maiores exigências sobre as respectivas atividades e abertura de novas plantas processadoras em outras regiões. Os reflexos dessas mudanças, oriundas do que se pode indicar, genericamente, como pressões da globalização sobre as empresas, inculcaram na área a ideia de crise. Muitas famílias deixaram as áreas rurais, alimentando fluxos migratórios que geraram declínio populacional em vários municípios. Mas também surgiram ações que redundaram na instalação de agroindústrias rurais familiares e em redes de cooperação atuando em produção e venda de itens coloniais. Apoiadas institucionalmente, essas iniciativas certamente expressaram espírito de reciprocidade e cooperação, traços herdados - e valorizados ou promovidos - das relações comunitárias ou de vizinhança e solidariedade que pontilharam histórias e experiências compartidas desde os primórdios da colonização.

Como interpretar as aparentes diferenças de cultura de vínculo social manifestadas nas três regiões, todas com registros de trajetórias nas quais as dificuldades inerentes à colonização magnificaram, ao menos inicialmente, a importância da reciprocidade, solidariedade, confiança mútua e ação conjunta?

Em grandes e exploratórios traços procurou-se sugerir, nas abordagens individuais, que no Vale do Itajaí e no norte moveleiro, a possível presença de um mais ou menos enraizado (embedded) habitus marcado pela herança de reciprocidade, solidariedade, confiança mútua e ações coletivas, não teria logrado bloquear comportamentos com "espontaneidade" e "razão prática" crivados de forte 
rivalidade e pouco inclinados à construção conjunta de alternativas, para não falar em concorrência desleal e destrutiva. O oeste catarinense apresenta situação diferente, e uma conjectura - nada mais do que isso - sobre a causa pode ser esboçada evocando-se a ruralidade incrustada nessa região, provavelmente caracterizada por maior homogeneidade cultural e socioprofissional e fértil para o florescimento, frente aos problemas, de ações coletivas permeadas do sentido de reciprocidade.

De fato, no oeste catarinense, as mudanças na agroindústria atingiram muitas propriedades rurais, e foi na esfera comunitária que, aparentemente, protagonizouse o essencial do tipo de reação descrita, em atitudes registradas na escala das interações de vizinhança, com apoio institucional. Não seria equivocado considerar que, no meio rural, o ambiente de reciprocidade-solidariedade típico da colonização foi melhor preservado - o que remete ao respectivo habitus -, influenciando decisões e práticas em face das vicissitudes. Assinale-se que o Fórum de Desenvolvimento Regional Integrado (FDRI), surgido em Chapecó em meados dos anos 1990 no âmbito da Associação dos Municípios do Oeste de Santa Catarina com atividades executadas pelo SAGA Instituto de Desenvolvimento Regional, criado como braço operacional do FDRI -, representou iniciativa que procurou valorizar esses aspectos regionais (LINS, 2011).

No Vale do Itajaí e no norte moveleiro, em ambientes urbano-industriais onde as reações às novas condições surgiram mormente nos atores corporativos, registraram-se respostas em que a "razão prática" pouco evocou aqueles elementos do assinalado habitus. Isso há de guardar relação com o fato de a própria trajetória setorial e regional ter produzido profunda diferenciação nesses tecidos produtivos, expressa em aspectos como escala, tecnologia e desempenho comercial das empresas.

\section{Considerações finais}

Sinônimos de grandes desafios, os processos costumeiramente indicados em referência à globalização tendem a afetar territórios e atividades de maneiras diversas. A capacidade de reagir, no nível regional ou local, aos imperativos de um capitalismo tipificado por interdependências em escala planetária, e o modo como as respostas são concebidas, se expressam e repercutem, refletiria, entre outras coisas, a influência de atributos historicamente plasmados que abrangem aspectos econômicos, socioculturais e institucionais. Haja vista a diversidade de situações 
quanto a tais aspectos, faz sentido falar em algo como "sociologia do lugar" no tocante ao assunto.

Este estudo, de índole exploratória, foi elaborado com inspiração nessa ideia de "sociologia do lugar". Assim, foram abordados problemas ou movimentos, no Vale do Itajaí têxtil e do vestuário, no norte moveleiro e no oeste agroindustrial, que se percebeu serem condizentes com tal sociologia, realçando a problemática dos vínculos sociais nas ações protagonizadas em face das adversidades.

Examinou-se um ângulo específico da questão relativa ao modo como a dinâmica do que se chama genericamente de globalização afetou - sobretudo desde a última década do século passado - as estruturas regionais e provocou respostas (ou deixou de ensejar o que se esperaria ser mais adequado, representando isto um modo de se perfilar diante dos desafios). Naturalmente, diversos pontos ficaram de fora do estudo. Outras perspectivas de análise certamente enfatizariam aspectos distintos dos que foram tangenciados aqui.

Assinale-se também que as imagens produzidas neste trabalho, sobre o Vale do Itajaí têxtil e do vestuário, o norte moveleiro e o oeste agroindustrial, são as que puderam ser vislumbradas com base nos diversos estudos setoriais e regionais consultados. Do que foi possível observar, e ciente das particularidades nas três realidades observadas, parece plausível postular que teria importância, perante novos e interpeladores desafios e adversidades para grupos sociais e agentes econômicos, a constituição nessas áreas do que se poderia designar, não sem alguma grandiloquência, como coalizões para o desenvolvimento.

Essa postulação parece ter sentido não só para as situações consideradas no artigo, mas também, possivelmente, para outras mais ou menos semelhantes, de uma forma geral. Com efeito, "coesão territorial" pode representar uma espécie de ideia-força com respeito à promoção do desenvolvimento na escala local ou regional, embora nada garanta que uma condição com tal perfil seja de fato possível e progrida, haja vista ser regra a diversidade (e o conflito) de interesses.

\section{REFERÊNCIAS}

BECATTINI, G. Le district marshallien: une notion socio-économique. In: BENKO, G.; LIPIETZ, A. (Dirs.). Les régions qui gagnent. Paris: Presses Universitaires de France,1992, p. 35-55.

BENKO, G.; LIPIETZ, A. (Dirs.). Les régions qui gagnent. Paris: Presses Universitaires de France, 1992. 
BENKO, G.; LIPIETZ, A. (Dirs.). La richesse des régions: la nouvelle géographie socioéconomique. Paris: Presses Universitaires de France, 2000.

BOURDIEU, P. Le champ économique. Actes de la Recherche en Sciences Sociales, $n$. 119, p. 48-66, 1997.

BOURDIEU, P. O poder simbólico. 5.ed. Rio de Janeiro: Bertrand Brasil, 2002.

CARIO, S.A.F. et al. Indústria e arranjos produtivos locais em Santa Catarina: avaliação e política de desenvolvimento para setores tradicionais. Florianópolis: Nova Letra, 2013.

CARNEY, J.; HUDSON, R.; LEWIS, J. (Eds.). Regions in crisis: new perspectives in European regional theory. London: Croom Helm, 1980.

CATTANEO, O.; GEREFFI, G.; STARITZ, C. (Eds.). Global value chains in a postcrisis world: a development perspective. Washington, D.C.: The World Bank, 2010.

COLETTI, T.; LINS, H. N. (2011). A suinocultura no vértice das relações entre agroindústria e agricultura familiar no oeste de Santa Catarina. Ensaios FEE, v. 32, n. 2, p. 339-360, 2011.

COMERLATTO, L. M.; LINS, H. N. Produção moveleira em São Bento do Sul (SC): a perspectiva das cadeias mercantis globais. Ensaios FEE, v. 29, n. 2, p. 503-530, 2008.

CONCLA - Comissão Nacional de Classificação; IBGE - Instituto Brasileiro de Geografia e Estatística. Classificação Nacional de Atividades Econômicas (CNAE). Rio de Janeiro: IBGE, 2002. Obtido em: <https://biblioteca.ibge.gov.br/visualizacao/livros/liv1358.pdf> Acesso em: 12 dez. 2018.

DENK, A. Polos moveleiros: I - São Bento do Sul (SC). São Paulo: ABIMÓVEL, 2002.

DENK, A.; CARIO, S. A. F. Análise das condições competitivas do cluster moveleiro da região de São Bento do Sul em Santa Catarina. In: CARIO, S. A. F.; PEREIRA, L. B.; SCHÜNEMANN, A. J. (Orgs.). Características da estrutura de mercado e do padrão de concorrência de setores industriais selecionados de Santa Catarina. Florianópolis: PPGECo-UFSC, 2002, p. 271-301.

DIVISÃO regional do Brasil em regiões geográficas imediatas e regiões geográficas intermediárias: 2017. Rio de Janeiro: IBGE, 2017.

FERRARI, Dilvan L.; T|ORESAN, Luiz; MIOR, Luiz C.; MARCONDES, Tabajara. As mudanças estruturais na agricultura catarinense: análise a partir dos censos agropecuários. In: GOVERNO DE SANTA CATARINA. Empresa de Pesquisa Agropecuária e Extensão Rural de Santa Catarina - Epagri. Centro de Socioeconomia e Planejamento Agrícola Cepa. Síntese anual da agricultura de Santa Catarina 2017-2018. Florianópolis: Epagri/Cepa, 2019, p. 7-20.

FICKER, C. São Bento do Sul: subsídios para a sai história. 1aㅡ Parte. Joinville: Impressora Ipiranga, 1973.

FREITAG, K. C., BRANDÃO, L. As transformações no mundo do trabalho em Blumenau/SC: a gestão dos benefícios sociais. II JORNADA NACIONAL DE DESENVOLVIMENTO E POLÍTICAS PÚBLICAS, Criciúma: Universidade do Extremo Sul Catarinense, 2018.

GEREFFI, G. International trade and industrial upgrading in the apparel commodity chain. Journal of International Economics, n. 48, p. 37-70, 1999.

GOVERNO DE SANTA CATARINA. Empresa de Pesquisa Agropecuária e Extensão Rural de Santa Catarina. Centro de Socioeconomia e Planejamento Agrícola. Síntese annual da agricultura de Santa Catarina 2017-2018. Florianópolis: Epagri/Cepa, 2019.

GRANOVETTER, M. Economic action and social structure: the problem of embeddedness. American Journal of Sociology, v. 91, n. 3, p. 481-510, 1985.

HARVEY, D. (1995). Globalization in question. Rethinking Marxism, v. 8, n. 4, p. 1-17, 1995. 
HELFAND, S. M.; REZENDE, G. C. Mudanças na distribuição espacial da produção de grãos, aves e suínos no Brasil: o papel do Centro-Oeste. Planejamento e Políticas Públicas, n. 611, p. 219-273, 1999.

HERING, M. L. R. Colonização e indústria no Vale do Itajaí: o modelo catarinense de desenvolvimento. Blumenau: Editora da Universidade Regional de Blumenau, 1987.

IBGE. Censo agropecuário 1995-1996. Obtido em: https://sidra.ibge.gov.br/pesquisa/censo-agropecuario/censo-agropecuario-1995-1996

Acesso em: 15 jan. 2020.

IBGE. Censo agropecuário 2006. Obtido em: https://sidra.ibge.gov.br/pesquisa/censoagropecuario/censo-agropecuario-2006/segunda-apuracao Acesso em: 15 jan. 2020.

IBGE. Censo agropecuário 2017. Obtido: https://sidra.ibge.gov.br/pesquisa/censoagropecuario/censo-agropecuario-2017 Acesso em: 15 jan. 2020.

JONES, R.; KIERZKOWSKI, H. International fragmentation and the new economic geography. North American Journal of Economics and Finance, n. 16, p. 1-10, 2005.

KAPLINSKY, R.; MMEDOVIC, O.; MORRIS, M.; READMAN, J. The global wood furniture value chain: what prospects for upgrading by developing countries. The case of South Africa. Vienna: United Nations Industrial Development Organization, 2003.

LANZER, E.; CASAROTTO Fo, N.; CUNHA, C. Análise da competitividade sistêmica do setor de móveis de Santa Catarina. Florianópolis: BRDE, 1998.

LAZZARI, M. R. Avicultura de corte no Brasil: uma comparação entre as Regiões Sul e Centro-Oeste. Indicadores Econômicos FEE, v. 31, n. 4, p. 259-290, 2004.

LINS, H. N. Reestruturação industrial em Santa Catarina: pequenas e médias empresas têxteis e vestuaristas catarinenses perante os desafios dos anos 90 . Florianópolis: Editora da UFSC, 2000.

LINS, H. N. Arranjo produtivo têxtil-vestuarista da região do Vale do Itajaí. In: CARIO, S.A.F. et al. (Orgs.). Economia de Santa Catarina: inserção industrial e dinâmica competitiva. Blumenau: Letra Nova, 2008, p. 336-381.

LINS, H. N. Descentralização do Estado: discutindo o planejamento e a promoção do desenvolvimento com dimensão espacial. Revista da Sociedade Brasileira de Economia Política, n. 28, p. 71-101, 2011.

LINS, H. N. Mudanças econômicas e possibilidades dos territórios: observações sobre a trajetória recente do oeste de Santa Catarina. Revista Catarinense de Economia, v. 1, n. 1, p. 94-119, 2017.

LINS, H. N. Reestruturação produtiva, efeitos regionais e busca de alternativas: o oeste catarinense em foco. XIII ENCONTRO NACIONAL DE ECONOMIA POLÍTICA, Niterói, UFFSEP, jun. 2018. Anais...

LINS, H. N. Reestruturação produtiva e reconfiguração espacial da indústria do vestuário em Santa Catarina: contextualização do tema e indícios sobre o começo do século XXI. XIII ENCONTRO DE ECONOMIA CATARINENSE, Criciúma, UNESC-APEC, maio 2019, Anais, p. 986-1012.

LINS, H. N.; GUIMARÃES, P. A. Promovendo exportações de móveis: aspectos da implementação do PROMÓVEL no aglomerado moveleiro de São Bento do Sul (SC). Revista de Economia, v.34, n. 3, p. 7-33, 2008.

LINS, H. N.; SOUSA, G. R. de. Exercício de "história local": uma saga na trajetória moveleira do planalto norte catarinense. História Econômica \& História de Empresas, v. 17, n. 2, p. 605-628, 2014.

LIPIETZ, A. Aménagement du territoire et développement endogène. Paris: CEPREMAP, 2001. 
LUNDVALL, B.; BORRÁS, S. The globalising learning economy: implications for innovation policy. Brussels: European Commission, 1997.

MARCONDES, T.; MIOR, L. C.; REITER, J. M. W.; MONDARDO, M. Os empreendimentos de agregação de valor e as redes de cooperação da agricultura familiar de Santa Catarina. Florianópolis: EPAGRI, 2012.

MARSHALL, A. Principles of economics: an introductory volume. 8.ed. London: Macmillan, 1979.

MIOR, L. C. Agricultores familiares, agroindústrias e redes de desenvolvimento rural. Chapecó: Argos, 2005.

OECD. Interconnected economies: benefiting from global value chains. Paris: OECD Publishing, 2013.

PAIM, E. A. Aspectos da construção histórica da região oeste de Santa Catarina. SAECULUM - Revista de História, n. 14, p. 121-138, 2006.

POLI, O. L. Cultura e modo de vida camponês no oeste catarinense: as bases para a organização e reação frente à crise dos anos 70 . Cadernos do CEOM, v. 16, n. 5, p. 107175, 2002.

POLO moveleiro catarinense reverte estratégia de vendas para evitar colapso. AN, [S.p.], 4 abr. 2014. Obtido em: https://www.nsctotal.com.br/noticias/polo-moveleiro-catarinensereverte-estrategia-de-vendas-para-evitar-colapso Acesso em: 14/01/2020.

RAIS - Relação Anual de Informações Sociais. Brasília, D.F.: Ministério do Trabalho, S.d. Obtido em: <http://bi.mte.gov.br/bgcaged/rais.php> Acesso em: 11 jan. 2020.

RODRIK, D. Has globalization gone too far? Washington, DC: Institute for International Economics, 1997.

SEABRA, F.; PAULA, D. de; FORMAGGI, L. Arranjo produtivo de móveis da região de São Bento do Sul. In: CARIO, S.A.F. et al. (Orgs.). Economia de Santa Catarina: inserção industrial e dinâmica competitiva. Blumenau: Letra Nova, 2008, p. 268-296, 2008.

SHEPHERD, B.; STONE, S. Global production networks and employment: a developing country perspective. OECD Trade Policy Papers, n. 154, Paris: OECD Publishing, 2013.

SILVA, A. da; ROSA, A. da. Antes do Oeste Catarinense: aspectos da vida econômica e social de uma região. Fronteiras: Revista Catarinense de História, n. 18, p.139-160, 2010.

SILVA, C. A.; HEIDEN, F. C.; AGUIAR, V. V. P.; PAUL, J. M. Migração rural e estrutura agrária no oeste catarinense. 2.ed. Florianópolis: Instituto CEPA, 2003.

STORPER, M.; HARRISON, B. Flexibility, hierarchy and regional development: the changing structure of industrial production systems and their form of governance in the 1990s. Research Policy, v. 20, n. 5, p. 407-422, 1991.

TESTA, V. M.; NADAL, R.; MIOR, L. C.; BALDISSERA, I. T.; CORTINA, M. 0 desenvolvimento sustentável do Oeste Catarinense (proposta para discussão). Florianópolis: EPAGRI, 1996.

THEIS, I. M.; NODARI, T. M. dos S. A agroindústria de aves e o desenvolvimento regional no Meio Oeste de Santa Catarina. Cadernos de Economia, v. 4, n. 7, p. 7-28, 2000.

VANIER, M. (Dir.) Territoires, territorialité, territorialisation: controverses et perspectives.

Rennes: Presses Universitaires de Rennes, 2009. 


\section{NOTAS DE AUTOR}

\section{CONTRIBUIÇÃO DE AUTORIA}

Hoyêdo Nunes Lins - Concepção. Coleta de dados, Análise de dados, Elaboração do manuscrito, revisão e aprovação da versão final do trabalho. Em suma, tudo o que resultou no artigo.

\section{FINANCIAMENTO}

Não se aplica.

\section{CONSENTIMENTO DE USO DE IMAGEM}

Não se aplica.

\section{APROVAÇÃO DE COMITÊ DE ÉTICA EM PESQUISA}

Não se aplica.

\section{CONFLITO DE INTERESSES}

Não se aplica.

\section{LICENÇA DE USO}

Este artigo está licenciado sob a Licença Creative Commons CC-BY. Com essa licença você pode compartilhar, adaptar, criar para qualquer fim, desde que atribua a autoria da obra.

\section{HISTÓRICO}

Recebido em: 12-06--2020

Aprovado em: 01-02-2021 